\title{
THE SYSTEM OF EVALUATING THE EFFECTIVENESS OF EMPLOYEES MOTIVATION AS A FACTOR OF THE ENTERPRISE SUSTAINABLE DEVELOPMENT
}

\author{
Tetyana Korytko ${ }^{1}$, Samira Piletska ${ }^{2}$, Olena Arefieva ${ }^{3}$, Yelizoveta Pidhora ${ }^{4}$, Inna Fomichenko ${ }^{5}$
}

${ }^{1}$ Ph. D. in Economics, Associate Professor,Institute of Industrial Economics of National academy of sciences of Ukraine, Ukraine, E-mail address: taniakorytko@gmail.com

${ }^{2}$ Doctor of Economics, Associate Professor, National Aviation University, Ukraine; E-mail: 0508486185@ukr.net

${ }^{3}$ Doctor of Economics, Professor, Head of the Department of economy of Air Transport, National Aviation University, Kyiv, Ukraine, E-mail address: Elena-2009-19@ukr.net

${ }^{4} \mathrm{PhD}$ (Engineering), Associate Professor, Donbass State Engineering Academy, E-mail address: podgora.elis@gmail.com

${ }^{5}$ Ph. D. in Economics, Associate Professor, Donbass State Engineering Academe, Ukraine, E-mail address: inna_fomichenko@ukr.net

Received 2610 2021; Accepted 04112021

\begin{abstract}
An important prerequisite for the development of modern society in the maximum use of innovations is the special attention of the personnel, which creates conditions for economic growth and competitiveness of both the individual employee and the company as a whole, as well as guarantees its economic security. In addition to certain labor conditions at an industrial enterprise, each employee has his/her own personal motives and incentives that motivate $\mathrm{him} /$ her to perform the tasks assigned to him on a daily basis. In this regard, the purpose of this research is to develop methodological frameworks for evaluating the effectiveness of the employees' incentives system to increase the intellectualization of the enterprise and identify priority areas for improving their coordination to ensure the sustainable economic development. The article formulates criteria for evaluating the effectiveness of the employees' incentives system for to increase the intellectualization of the enterprise, which include indicators of balance, resource intensity, social activity etc. On the basis of the specified indicators the evaluation of efficiency of the employees' incentives system to increase the enterprise intellectualization is carried out and measures for stimulation of employees to the further development of the enterprise are developed.
\end{abstract}

Keywords: motivation, incentives, employees, intellectualization, enterprise, system, efficiency.

JEL Codes: L510, M54.

\section{Introduction}

The innovative paradigm of economic development necessitates the development of modern management methods and tools aimed at identifying and effectively using the internal potential of the enterprise, taking into account the specifics of its activities. Industrial enterprises face a set of complex problems related to the management of their activities. In this aspect, of particular importance are the issues of stimulating the labor activity of employees, the solution of which allows the fullest use of available labor potential and thus makes it possible to increase the socio-economic efficiency of any production.

Copyright (C) 2021 Author(s), published by Vytautas Magnus University. This is an open access article distributed under the terms of the Creative Commons Attribution Non-Commercial 4.0 (CC BY-NC 4.0) license, which permits unrestricted use, distribution, and reproduction in any medium provided the original author and source are credited. The material cannot be used for commercial purposes. 


\section{Literature review}

Motivation and stimulation as methods of labor management are opposite in direction: the first is aimed at changing the existing situation; the second is aimed to consolidate it, but at the same time they complement each other. The function of stimulation, according to Kilelyova E.A. (2008), is that it affects the labor force in the form of incentives for efficient work, social influence, team and individual incentives.

Thus, motivation makes and persuades people to do something. However, motivation reflects a general desire. Wanjau et al. (2013) noted that both punishment and encouragement act as methods of motivation and they are observed in various studies. In this regard, the material component - the money is considered as a tool of remuneration, but it is not the only motivating factor.

Employee motivation should be considered, according to Hitka et al. (2019) as a psychological process that stimulates and supports human activity. Employee motivation is the main component of the management process, and relevant knowledge on these issues should be obtained by the company authorities. Motivation is the driving force through which companies make an effort in the hope of achieving their goal. The motives for the measures taken may vary depending on the needs of the person, the workplace and the cultural environment, as well as the potential to achieve a certain goal. Thus, motivation is a desire, intention or wish to achieve something. This is a psychological process that all employees experience in the workplace; this is the main element of their labor potential, while their effectiveness determines the level of their competence. On the other hand, motivation aims to increase the level of intellectualization of the enterprise (Cantele et al. 2018; Cequea et al. 2011).

Motivation is not homogeneous. Some studies indicate differences in the employee motivation. Such differences are regional and cultural (Hitka et al. 2019), depending on age and stage of professional career (Gursoy et al. 2008; Caganova et al. 2017) associated with belonging to a given generation (Collier 2017; $\mathrm{Ng}$ and Schweitzer 2010; Curry 2015) or is determined by the level of education (Schoroder 2008).

Using the standard method of the staff motivation as a fixed salary, the manager may not be interested in the employee to work effectively to increase the level of the enterprise intellectualization. It is necessary to use several motivating factors (because a person has many needs, and they are not always limited to material rewards). A nonefficient system of motivation leads only to temporary success and leads to a loss in the form of turnover of highly qualified personnel due to the weak relationship between the interests of the company and its employees and reflects on increased tensions in the socio-and-psychological environment (Ghanbarpour et al., 2013).

It should be noted that in the literature the terms "motivation" and "stimulation" are often identified or considered as close synonyms. They also often interpret the essence of motivation through stimulation (and vice versa). In particular, Korytko T. in the work (2018) understands motivation as "the external process of influencing the formation of a person's motive for activity", thus identifying the concepts of motivation and stimulation. From the point of view of Samigin (1997), motivation is "the function of management, stimulating an individual employee or group to take actions that lead to the achievement of the organization's goals." To refute or confirm this thesis, we also consider the meaning of the "incentive" concept.

The study of methodological literature on the development and implementation of the labor motivation systems at the enterprises revealed the following three interrelated components (groups of methods) of work motivation. Among them are administrative, economic and social elements (Piletska et al., 2020; Bryl et al., 2018, Mahmood et al., 2016). 
Kamalian et al. (2010) notes that the motivated employee's goals coincide with the goals of the enterprise, and they accordingly aim their efforts at the success of production. Incentives are considered as the main factors that motivate employees to work efficiently. In other words, the system of incentives and rewards expands the opportunities of employees and facilitates the achievement of the goals of institutions (Baba et al., 2011). The lack of an appropriate incentive scheme can negatively affect employee productivity. There is no achievement of the enterprise's goals (Palmer, 2012). Incentives can be financial or non-financial. While financial incentives are mainly monetary in nature, such as salary supplements or profit sharing, non-financial incentives are non-monetary and include motivation, praise and appreciation from the manager, attention from the authorities, opportunities to manage projects or working groups, subsidized staff transportation and granting, etc. (Kompaso et al., 2010) suggested that managers should use financial and non-financial benefits to encourage employees to be more loyal. In the existing research, much attention is paid to profit (Ogbonnaya et al., 2017). Profit distribution can be considered as participation as opposed to benefits. This is due to the establishment of a causal link between any incentives and the degree of the employees' loyalty to the enterprise management. Protsik (2007); V. Sladkevich (2001); A. Kolot (2002) consider stimulation as a process of influencing an employee in order to awaken in him certain motives, but this process differs from motivation.

Employee incentives are the process of forming, developing and implementing strategies and policies that focus on achieving the enterprise's goals by involving and retaining professionally trained staff and, above all, by efficient, strong and sustainable motivation, formed on the basis of comprehensive incentives, which is of interest to all groups of personnel at the enterprise. First of all, it means rewarding people according to their significance to the enterprise, which is measured by their current and potential contribution to the results.

There is a need for further research to evaluate the system of incentives for employees to increase the intellectualization of the enterprise. It is advisable to improve the methodological approach to evaluating the effectiveness of the employees' incentives system to increase the intellectualization of the enterprise in order to motivate employees to increase the incentives for intellectualization of the enterprise.

The article aims to improve the theoretical and methodological basis for evaluating the effectiveness of the employees' incentives system to increase the intellectualization of the enterprise.

The purpose of the article is to strengthen the theoretical and methodological basis for evaluating the effectiveness of the employees' incentives system to increase the intellectualization of the enterprise and identify priority areas for improving their coordination to ensure sustainable economic development.

\section{Methodology}

Evaluating the efficiency of the incentives system to increase the intellectualization of the enterprise will help to understand the way of the rational use of financial resources, appropriate moral and social methods of motivation to improve productivity and work quality.

When developing a methodology for evaluating the efficiency of the employees' incentives system to increase the intellectualization of the enterprise, it is important to use those indicators that will most fully reflect the specifics of this industry. The efficiency indicator is a quantitative or qualitative feature of the work of the object of management (employee, structural unit, enterprise), which determines the effectiveness degree of managerial influence. 
The indicator should:

1) meet the goals and objectives of the motivation system;

2) be informative, i.e. with a certain degree of probability to assess the actual state of the control system and predict the expected result in the future;

3) be available for collection of initial data and further analysis;

4 ) be studied in the dynamics.

Shostka (2015) suggests calculating an integrated indicator for evaluating the employees' incentive systems by the following components: the balance of the incentives systems; resource intensity of incentives systems; performance of incentives systems.

According to Elvseev (2015), the evaluation of the employees' incentives system should be carried out on the basis of the following groups of indicators: means of material, organizational and sociopsychological incentives.

The value of an indicator at a particular time is in itself insignificant. In order to make informed management decisions, it is important to analyze the indicators in the dynamics, so the method of obtaining them should be virtually unchanged, and the form of collection, accumulation and analysis of information - easy to use.

In order to evaluate the employees' incentives system to increase the intellectualization of the enterprise, it is recommended to use a minimum quantity of indicators sufficient to obtain results to characterize each of the components (Fig. 1). The selected indicators meet the criteria of accessibility and in formativeness, which ensures the simplicity and convenience of their application in practice. If it is necessary to carry out a more in-depth analysis in practical conditions, these indicators can be supplemented or replaced by others based on the features of a particular enterprise. 
Management Theory and Studies for Rural Business and Infrastructure Development eISSN 2345-0355. 2021. Vol. 43. No. 4: 545-554

Article DOI: https://doi.org/10.15544/mts.2021.49

The employees' incentives system to increase the intellectualization of the enterprise

Components of evaluating the effectiveness of the management system

\begin{tabular}{|c|c|c|}
\hline $\begin{array}{l}\text { Balance: } \\
\text { - growth rate of the average } \\
\text { qualification level of } \\
\text { employees; } \\
\text { - employee turnover rate; }\end{array}$ & $\begin{array}{l}\text { Resource consumption: } \\
\text { - coefficient of the plan } \\
\text { implementation; } \\
\text { - share of private enterpreneur } \\
\text { staff; } \\
\text { - the ratio of the average salary } \\
\text { of employees; } \\
\text { - profit of expenditures for } \\
\text { material incentives for } \\
\text { employees }\end{array}$ & $\begin{array}{l}\text { Social activity: } \\
\text { - employees' satisfaction with the level } \\
\text { of salary; } \\
\text { - employees' satisfaction with the } \\
\text { fairness of material incentives; } \\
\text { - employees' satisfaction with social } \\
\text { guarantees and payments; } \\
\text { - employees' satisfaction with the } \\
\text { moral and psychological environment }\end{array}$ \\
\hline
\end{tabular}

The level of efficiency of the employees' incentives system to increase the intellectualization of the enterprise
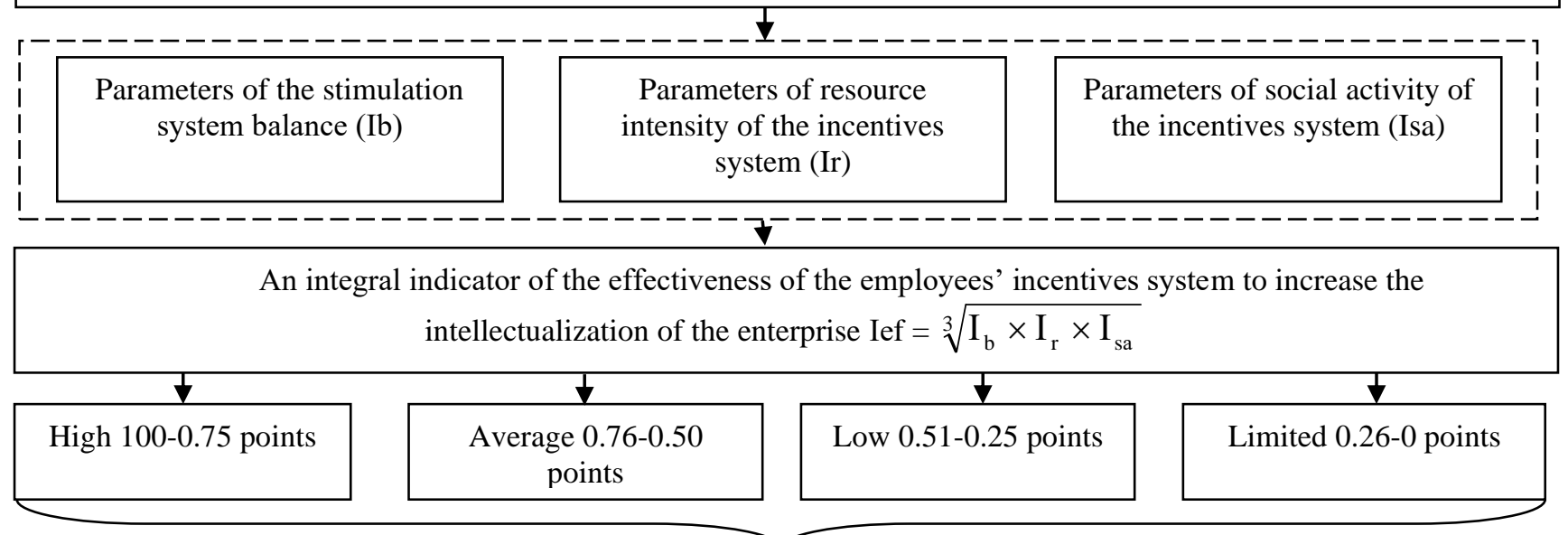

Efficiency of use of resources on the employees'stimulation to increase intellectualization and efficiency of the enterprise activity

\section{the intellectualization of the enterprise in order to ensure the sustainable development \\ *Source: described by the authors}

Focusing on the fact that one of the goals of employee remuneration systems is to increase their motivation to increase the intellectualization of the enterprise, the following method is suggested to evaluate the effectiveness of the employees' incentives system, including a set of indicators to evaluate the «economic» and «social» components of the efficiency, taking into account the effect for both employees and employers.
It is suggested diagnosing the effectiveness of the employees' incentives systems and its impact on the activity by calculating the integrated indicator in the following stages.

At the first stage, the calculation is made of each of the indicators. It is recommended to calculate them based on the results of the year, but it is possible to reduce the interval (six months, a quarter).

1. Indicators that characterize the balance of the employees' incentives system to increase the intellectualization of the 
enterprise. This group of indicators includes: the growth rate of the average qualification level of employees $(\mathrm{T})$; the employee turnover ratio $(\mathrm{Ke})$.

2. Indicators that characterize the resource intensity of the employees' incentives system to increase the intellectualization of the enterprise.

This group of indicators includes: the coefficient of implementation of the plan $(\mathrm{Kn})$, the share of the payroll, which adapted to increase the intellectualization of the enterprise in the total payroll (Dn), the ratio of the average salary of employees engaged in innovation in the enterprise to the total salary fund (Df), for material incentives for employees $(\mathrm{Bm})$.

3. Indicators that characterize the social activity of the employees' incentives system to increase the intellectualization of the enterprise. This group of indicators includes: employee satisfaction with the level of wages (K1), fairness (K2), social guarantees (K3), moral and psychological environment at the enterprise (K4).

At the second stage, the level of efficiency of the system of incentives for employees to increase the intellectualization of enterprises is determined.

The degree of the compliance of the targets is evaluated on a scale from 0 to 10 points.

An expert method is used to evaluate the value factor of the sub-criterion. For this purpose, a sample of respondents was conducted, which included specialists involved in evaluating the intellectualization of enterprises and the leading specialists of enterprises. Substantiation of the value of the coefficients, which is used to evaluate the adaptation of employees to increase the intellectualization of the enterprise, was carried out.

For this purpose, it is recommended to carry out an individual point estimation of employees' adaptation to increase the intellectualization of the enterprise on the basis of the suggested criteria (Table 1). These indicators do not allow a comprehensive evaluation of the employee, because each person is full of only individual features.

Table 1. The scale of points on the indicators of assessing the effectiveness of the system of incentives for employees to increase the intellectualization of the enterprise

\begin{tabular}{|c|c|c|c|c|c|c|c|c|c|c|c|c|c|}
\hline \multirow{2}{*}{$\begin{array}{c}\text { Show } \\
\text { evaluation }\end{array}$} & \multirow{2}{*}{$\begin{array}{c}\text { Go nice } \\
\text { measurement }\end{array}$} & \multicolumn{11}{|c|}{ points } & \multirow{2}{*}{$\begin{array}{l}\text { weight } \\
\text { value of } \\
\text { the } \\
\text { indicator }\end{array}$} \\
\hline & & 10 & 9 & 8 & 7 & 6 & 5 & 4 & 3 & 2 & 1 & 0 & \\
\hline \multicolumn{13}{|c|}{1 Indicators that characterize the balance of the incentive system for employees } & 0,30 \\
\hline $\mathrm{T}$ & $\%$ & $\begin{array}{c}117- \\
\text { above }\end{array}$ & $\begin{array}{c}115- \\
116 \\
\end{array}$ & $\begin{array}{l}113- \\
114 \\
\end{array}$ & $\begin{array}{c}111- \\
112 \\
\end{array}$ & $\begin{array}{c}109- \\
110 \\
\end{array}$ & $\begin{array}{c}107- \\
108\end{array}$ & $\begin{array}{c}106- \\
105 \\
\end{array}$ & $\begin{array}{c}104- \\
105 \\
\end{array}$ & $\begin{array}{c}102- \\
103 \\
\end{array}$ & $\begin{array}{c}100- \\
101\end{array}$ & $\begin{array}{c}\text { Less } \\
100 \\
\end{array}$ & 0,4 \\
\hline Ke & $\%$ & $0-2$ & $3-5$ & $6-8$ & $9-11$ & $\begin{array}{c}12- \\
14 \\
\end{array}$ & $\begin{array}{c}15- \\
17 \\
\end{array}$ & $\begin{array}{l}18- \\
20\end{array}$ & $\begin{array}{l}21- \\
23 \\
\end{array}$ & $\begin{array}{c}24- \\
26 \\
\end{array}$ & $\begin{array}{l}27- \\
29 \\
\end{array}$ & $\begin{array}{c}30- \\
\text { more }\end{array}$ & 0,6 \\
\hline \multicolumn{13}{|c|}{2 Indicators that characterize the resource intensity of the employee incentive system } & 0,35 \\
\hline Kn & $\%$ & $\begin{array}{c}105- \\
\text { above }\end{array}$ & 104 & 103 & 102 & 101 & 100 & 99 & 98 & 97 & 96 & $\begin{array}{l}95- \\
\text { Less }\end{array}$ & 0,25 \\
\hline Dn & $\%$ & $\begin{array}{c}72- \\
\text { above }\end{array}$ & $\begin{array}{c}71- \\
69\end{array}$ & $\begin{array}{c}68- \\
66\end{array}$ & $\begin{array}{c}65- \\
63\end{array}$ & $\begin{array}{c}62- \\
60\end{array}$ & $\begin{array}{l}59- \\
57\end{array}$ & $\begin{array}{c}56- \\
54\end{array}$ & $\begin{array}{c}55- \\
53\end{array}$ & $\begin{array}{c}52- \\
50\end{array}$ & $\begin{array}{c}49- \\
47\end{array}$ & $\begin{array}{l}47 \text { - } \\
\text { Less }\end{array}$ & 0,2 \\
\hline Df & $\%$ & $\begin{array}{c}72- \\
\text { above }\end{array}$ & $\begin{array}{c}71- \\
69\end{array}$ & $\begin{array}{c}68- \\
66\end{array}$ & $\begin{array}{c}65- \\
63 \\
\end{array}$ & $\begin{array}{c}62- \\
60\end{array}$ & $\begin{array}{l}59- \\
57\end{array}$ & $\begin{array}{c}56- \\
54\end{array}$ & $\begin{array}{c}55- \\
53\end{array}$ & $\begin{array}{c}52- \\
50 \\
\end{array}$ & $\begin{array}{c}49- \\
47\end{array}$ & $\begin{array}{l}47 \text { - } \\
\text { Less }\end{array}$ & 0,3 \\
\hline $\mathrm{Bm}$ & $\%$ & $\begin{array}{c}5- \\
\text { above }\end{array}$ & 4 & 3 & 2 & 1 & 0,8 & 0,6 & 0,4 & 0,2 & 0,1 & 0 & 0,25 \\
\hline \multicolumn{13}{|c|}{3 Indicators that characterize the social activity of the employee incentive system } & 0,35 \\
\hline K1 & point & 10 & 9 & 8 & 7 & 6 & 5 & 4 & 3 & 2 & 1 & 0 & 0,35 \\
\hline $\mathrm{K} 2$ & point & 10 & 9 & 8 & 7 & 6 & 5 & 4 & 3 & 2 & 1 & 0 & 0,25 \\
\hline K3 & point & 10 & 9 & 8 & 7 & 6 & 5 & 4 & 3 & 2 & 1 & 0 & 0,25 \\
\hline K4 & point & 10 & 9 & 8 & 7 & 6 & 5 & 4 & 3 & 2 & 1 & 0 & 0,2 \\
\hline
\end{tabular}


It is suggested the usage one of the methods of factor analysis to combine the disparate indicators of the enterprise, namely, the method of principal components (MPC), by which it is advisable to determine the values of indicators that characterize the components of anti-crisis potential. Since the principal component method is based on the relationship of the original features, before constructing the principal components, it is necessary to check the correlation between X1 ... XP for each group of indicators.
At the third stage, a qualitative evaluation of the effectiveness of the employees' incentives system to increase the intellectualization of the enterprise is carried out. Based on the use of the Sturgess's formula, we will divide the value of the coefficient into appropriate groups. Qualitative characteristics of the employees' incentives system to increase the intellectualization of enterprises are given in Table 2 .

\section{Table 2. Scale of qualitative characteristics for evaluating the effectiveness of the employees' incentives system to increase the intellectualization of enterprises}

\begin{tabular}{|c|l|}
\hline $\begin{array}{c}\text { Number of } \\
\text { points }\end{array}$ & \multicolumn{1}{|c|}{ Characteristics of the of employees' incentives system } \\
\hline Ief $\geq \mathbf{1 0}$ & Area of high level of efficiency of enterprise incentives systems \\
\hline $\mathbf{8} \leq$ Ief $\leq \mathbf{1 0}$ & Area of normal level of efficiency of enterprise employees' incentives systems \\
\hline $\mathbf{5} \leq$ Ief $\leq \mathbf{8}$ & Area of low efficiency of enterprise employees' incentives systems \\
\hline Ief $<\mathbf{5}$ & Area of unsatisfactory level of use of employees' incentives systems (crisis situation). \\
\hline
\end{tabular}

*Source: described by the authors

Thus, the indicators that meet the conditions, namely, both reflect the economic and social efficiency and effectiveness of the employee and the employer. The ratio of indicators on various aspects of the effectiveness of the employees' incentives system to increase the intellectualization of the enterprise is suggested to be made on the use of Table 3.

Table 3. Matrix of the ratio of indicators on various aspects of the effectiveness of the system of employees' incentives systems to increase the intellectualization of the enterprise

\begin{tabular}{|c|c|c|}
\hline $\begin{array}{c}\text { Type of } \\
\text { efficiency }\end{array}$ & Efficiency for the employer & Efficiency for the employee \\
\hline 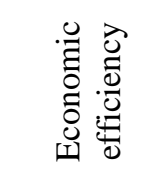 & $\begin{array}{l}\text { 1. The coefficient of the plan increase } \\
\text { 2. The growth rate of the average skilled level of } \\
\text { employees } \\
\text { 3. The coefficient of the employee turnover }\end{array}$ & $\begin{array}{l}\text { 1. The share of private entrepreneur staff who } \\
\text { have adapted to increase the intellectualization } \\
\text { of the enterprise in the total private } \\
\text { entrepreneur staff }\end{array}$ \\
\hline 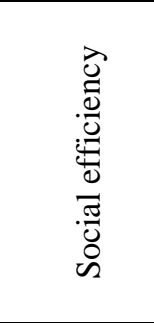 & $\begin{array}{l}\text { 1. The level of awareness of employees about the } \\
\text { mechanism of availability of all components of } \\
\text { salary and available at the enterprise social } \\
\text { benefits and moral incentives. } \\
\text { 2. The ratio of the average salary of employees } \\
\text { engaged in the enterprise innovation, to the total } \\
\text { amount of the salary fund. }\end{array}$ & $\begin{array}{l}\text { 1. Satisfaction of employees with the level of } \\
\text { salary } \\
\text { 3. Satisfaction of employees with the fairness } \\
\text { of material incentives } \\
\text { 4. Satisfaction of employees with social } \\
\text { guarantees and payments } \\
5 \text { Satisfaction of employees with the moral and } \\
\text { psychological environment at the enterprise }\end{array}$ \\
\hline
\end{tabular}

*Source: described by the authors 
The use of the suggested coefficients of the employees' incentives system to increase the intellectualization of the enterprise allows moving to a point evaluation of the efficiency level, in which diverse activities of the employees are quantified and determine the potential limits of the employees' intellectualization and their readiness to increase intellectualization.

\section{Research data}

The calculations were made of the efficiency of the employees' incentives system before and after the implementation of the suggested methods of employees' incentives to increase the level of intellectualization of the enterprise (Table 4).

Table 4. The results of evaluating the effectiveness of the system of incentives for employees to increase the intellectualization of enterprises

\begin{tabular}{|l|c|c|c|c|}
\hline & $\begin{array}{c}\text { I Indicators that } \\
\text { characterize the } \\
\text { balance of the } \\
\text { incentive system } \\
\text { for employees } \\
\text { Enterprises }\end{array}$ & $\begin{array}{c}\text { 2 Indicators that } \\
\text { characterize the } \\
\text { resource intensity } \\
\text { of the employee } \\
\text { incentive system }\end{array}$ & $\begin{array}{c}\text { 3 Indicators that } \\
\text { characterize the } \\
\text { social activity of } \\
\text { the employee } \\
\text { incentive system }\end{array}$ & Integral indicator \\
\hline DAP JSC & 7,56 & 6,15 & 8,03 & 7,72 \\
\hline NKMZ PJSC & 7,51 & 6,27 & 7,93 & 7,15 \\
\hline JSC «Hartron» & 7,53 & 6,64 & 7,33 & 7,36 \\
\hline $\begin{array}{l}\text { JSC THE KYIV FACTORY } \\
\text { RADAR }\end{array}$ & 7,13 & 6,08 & 7,78 & 6,84 \\
\hline PJSC "DATAGROUP" & 7,38 & 6,11 & 7,05 \\
\hline
\end{tabular}

*Source: constructed by the authors based on the evaluation results

The results of the calculations based on the suggested stages of evaluating the effectiveness of the employees' incentives system to increase the intellectualization of industrial enterprises are shown in Figure 2.

Analysis of indicators that determine the effectiveness of the employees' incentives system shows a low level of efficiency. It should be noted that none of the surveyed enterprises was included in the group with a high level of integrated indicator of the effectiveness of employees' incentives, which indicates the need to adjust the system of employees' incentives in all these enterprises. The low level is largely due to the unsustainable condition of these enterprises, which does not meet the conditions for ensuring an appropriate level of their employees' efficiency. 

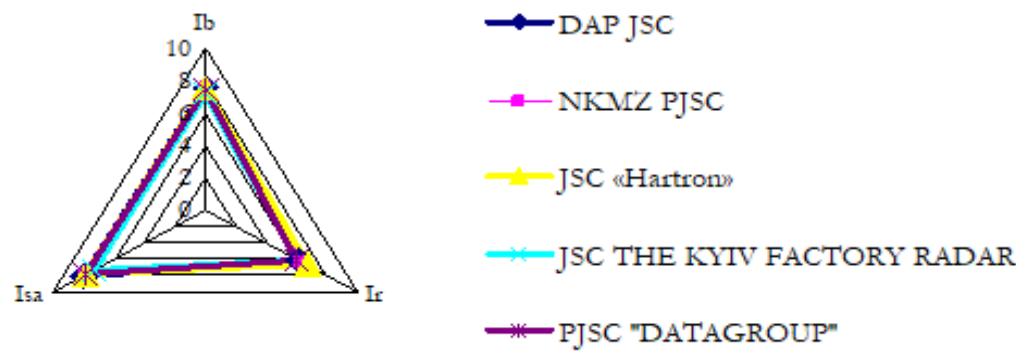

Figure 2. is a graphic interpretation of groups of indicators for evaluating the effectiveness of the employees' incentives system to increase the intellectualization of enterprises

*Source: constructed by the authors based on the evaluation results

Thus, it is determined that to improve the system of stimulating the intellectualization of the enterprise there are two interrelated processes: first, the selection of personnel with a set of motives aimed at improving the intellectualization of labor; secondly, the choice of appropriate incentives that can give the maximum result from the intellectualization of the enterprise.

Table 5 shows the methods of stimulating the employees to increase the intellectualization of the enterprise.

Table 5. Methods of stimulating employees to increase the intellectualization of enterprises

\begin{tabular}{|l|l|}
\hline Methods of stimulation & Methods of stimulation of the enterprise employee's intellectualization \\
\hline $\begin{array}{l}\text { Program of material } \\
\text { incentives }\end{array}$ & $\begin{array}{l}\text { Individualization of work, i.e the salary amount depends on education, intelligence, } \\
\text { creativity, professionalism, activity; from the final results of the team; use of royalties }\end{array}$ \\
\hline Facilitation of work & $\begin{array}{l}\text { Providing employees with more meaningful, interesting, important, work appropriate } \\
\text { to their personal interests and aptitudes; full recognition and adequate assessment of } \\
\text { the work performed }\end{array}$ \\
\hline Participation & $\begin{array}{l}\text { Involvement of employees in decision-making, participation in solving problems } \\
\text { related to work, division of responsibility for decisions }\end{array}$ \\
\hline Rotation & $\begin{array}{l}\text { More horizontal rotation, because the psychology of a creative person is such that he } \\
\text { does not rush to power; creating opportunities for professional development, self- } \\
\text { improvement }\end{array}$ \\
\hline $\begin{array}{l}\text { Synectics - a method of } \\
\text { stimulating creative activity }\end{array}$ & $\begin{array}{l}\text { Creating special conditions that stimulate the promotion of unexpected and non- } \\
\text { stereotypical analogies and associations to the task }\end{array}$ \\
\hline
\end{tabular}

Thus, the orientation of the company's management on the individual abilities and goals of the employee allows influencing them by material and social motives.

\section{Conclusion}

Evaluation of the incentives effectiveness for personnel of enterprises is based on the use of a methodological approach that allows increasing the efficiency of systems based on the evaluation by belonging to a certain group of indicators that form a single integrated indicator. It is offered to diagnose the effectiveness of the employees' incentives systems for by calculating the integrated indicator for the following components: "Balance of the incentives systems", "Resource capacity of the incentives systems"; "Social activity of incentives systems". The analysis of the suggested components provided an opportunity to comprehensively evaluate the effectiveness of the incentives systems for industrial enterprises. 


\section{References}

Baba, G. \& Bababe F. (2011). The effect of motivation workers performance. A case of Maiduguri Flour Mill Ltd, Borno State, Nigeria. Continental Journal of Social Sciences, 4(2), 8-13.

Bril, I., Koritko, T. (2018). Motivation and stimulation of innovation and investment activity of the enterprise. Business Inform, 5, 234-240.

Caganova, D., Starecek, A., Bednarikova, M. \& Hornakova, N. (2017). Analysis of factors influencing the motivation of generations $\mathrm{Y}$ and $\mathrm{Z}$ to perform in the educational process. In Proceedings of the 15th IEEE International Conference on Emerging eLearning Technologies and Applications (ICETA), Stary Smokovec, Slovakia, 26-27 October, 69-74.

Cantele, S. \& Zardini, A (2018). Is sustainability a competitive advantage for small business? An empirical analysis of possible mediators in the sustainability-financial relationship. J Clean Prod, 182, $166-176$. https://doi.org/10.1016/j.jclepro.2018.02.016

Cequea, M, \& Nunez Bottini, M. (2011). Human factors and influence on productivity. Revista Venezolana de Gerencia, 16(53), 116-137.

Curry, G.D. Supervising Across Generations. In Security Supervision and Managemenet, 4th ed. Butterworth: Oxford, UK, 2015.

Ghanbarpour, Z. \& Najmolhoda, F.S. (2013). Contemporary theories of motivation in organizational leadership and behavior. International Research Journal of Applied and Basic Sciences, 6(1), 1-7.

Gursoy, D, Maier, TA, \& Chi, C. (2008). Generational differences: an examination of work values and generational gaps in the hospitality workforce. International Journal of Hospitality Management, 27(3), 448-458. https://doi.org/ 10.1016/j.ijhm.2007.11.002

Hitka, M., Rózsa, Z., Potkány, M., \& Ližbetinová, L. (2019). Factors forming employee motivation influenced by regional and age-related differences. Journal of Business Economics and Management, 20(4), 674-693. https://doi.org/10.3846/jbem.2019.6586

Kamalian, A., Yaghoubi, N., \& Moloudi, J. (2010). Survey of relationship between organizational justice and empowerment (A case study). European Journal of Economics, Finance and Administrative Sciences, 24(2), $165-171$.

Kiseleva, E. (2008). Gender approach to staff motivation. Personnel management, 6, 14.

Kolot, A. (2002). Staff motivation. K: KNEU, 337.

Kompaso, S. \& Sridevi, M. (2010). Employee engagement: The key to improving performance. International Journal of Business and Management, 5(12), 89-96.

Korytko T., Piletska S.,Arefieva O., Pidhora Ye., \& Pryimakova Yu. (2020) Formation of organizational and economic mechanism of motivation of increase of investment activity of the interment. Financial and credit activities: problems of theory and practice, 4 (35), 418-425. DOI: doi.org/10.18371/fcaptp.v4i35.222446

Mahmood, A., Hussan, S. G., Sarfraz, M., Abdullah, M. I., and Basheer, M. F. (2016). Rewards Satisfaction, Perception about Social Status and Commitment of Nurses in Pakistan. European Online Journal of Natural and Social Sciences, 5(4), 1049.

$\mathrm{Ng}$, E., Schweitzer L., \& Lyons, S. (2010). New generation, great expectations: a field study of the millennia generation. Journal of Business and Psychology, 25(2), 281-292. https://doi.org/ 10.1007/s10869-010-9159-4

Ogbonnaya, C., Daniels, K. \& Nielsen, K (2017). How Incentive Pay Affects Employee Engagement,

Satisfaction, and Trust. Harvard Business Review. March, [Electronic resource]. - Access mode:

file:///C:/Users/Admin/Downloads/Ogbonnayaetal.2017-

HowIncentivePayAffectsEmployeeEngagementSatisfactionandTrust.pdf

Palmer W (2012). Incentive \& Disincentive: Will They Affect Performance.

Protsyk, I. (2007). Motivation of managers in the enterprise management system: dis. for science. degree of Cand. econ. Science: special. Lviv: National University. Lviv Polytechnic, 205.

Samygin, S. (1997). Personnel management. M. Zeus. 480.

Schoroder, R. (2008). Job satisfaction of employees at a Christian University. Journal of Research on Christian Education, 17(2), 225-246.

Shostak, I. (2015). Estimation of efficiency of systems of stimulation of work of personnel and their influence on efficiency of activity of the trade enterprise. Actual problems of economy. 5, 257-266.

Sladkevich, V. (2001). Motivational management. K. MAUP, 168.

Wanjau, M. \& Kyongo, J. (2013). Contribution of motivational management to employee performance. International Journal of Humanities and Social Science, 3(14), 219-239.

Yeliseyeva, O. \& Kutova N. (2017). Scientific Bulletin of the National Academy of Statistics. Accounting and Auditing. 1-2, 46-53. 